\title{
PENGARUH SUHU PENGERINGAN TERHADAP KANDUNGAN KOMPONEN BIOAKTIF DAN KARAKTERISTIK SENSORIS TEH WHITE PEONY
}

\author{
The Effect of Drying Temperature on The Bioactive Component Contents and Sensory
} Characteristics of White Peony Tea

\author{
Dewa Ayu Tri Ulandari ${ }^{1)}$, Komang Ayu Nocianitri ${ }^{2)}$, Ni Made Indri Hapsari Arihantana ${ }^{2}$ \\ ${ }^{1)}$ Mahasiswa Program Studi Ilmu dan Teknologi Pangan, Fakultas Teknologi Pertanian, Unud \\ ${ }^{2)}$ Dosen Program Studi Ilmu dan Teknologi Pangan, Fakultas Teknologi Pertanian, Unud \\ Kampus Bukit Jimbaran, Badung-Bali
}

\begin{abstract}
This study aims to determine the effect of drying temperature on the bioactive component contents of white peony tea and to know the proper drying temperature in white peony tea to produce the highest bioactive component contents and the best sensory characteristics. The experimental design used was Completely Randomized Design with a drying temperature as the treatment consisting of five levels: $60^{\circ} \mathrm{C}, 70^{\circ} \mathrm{C}, 80^{\circ} \mathrm{C}, 90^{\circ} \mathrm{C}$, and $100^{\circ} \mathrm{C}$. The treatment was repeated 3 times to obtain 15 experiment units. The data obtained were analyzed by variance and if the treatment had an effect on the observed variable then continued with The Duncan Multiple Range Test. The results showed that the $90^{\circ} \mathrm{C}$ drying temperature treatment produced white peony tea with the highest bioactive component contents and the best sensory characteristics with water content 4,06\% (wet basis), yield 52,54\%, total phenolic 211,01 mg GAE/g tea, flavonoid $10,90 \mathrm{mg} \mathrm{CE} / \mathrm{g}$ tea, catechin 3,55 mg/g tea, antioxidant activity 50,20\%, brew color yellow and liked, astringent taste and usual, aroma liked and overall acceptance rather liked.
\end{abstract}

Keywords : white peony tea, drying temperature, flavonoids, catechins, antioxidant activity

\section{PENDAHULUAN}

Teh putih adalah teh yang dibuat dari helaian pucuk daun Camellia sinensis yang masih sangat muda dan diolah tanpa melalui proses oksidasi enzimatis seperti pada pengolahan teh hitam dan teh oolong (Anon., 2013). Teh putih secara umum dikelompokkam menjadi dua jenis yaitu, silver needle dan white peony.

Teh silver needle merupakan jenis teh putih yang umumnya lebih dikenal masyarakat dibandingkan teh white peony, namun jika dibandingkan dengan teh silver needle, white peony termasuk jenis teh putih yang memiliki rasa lebih khas serta harga jual yang lebih terjangkau, sehingga saat ini teh white peony sedang dikembangkan di Bali oleh PT. Bali Cahaya Amerta, dimana tanaman teh khususnya varietas sinensis sebagai bahan baku pengolahan teh white peony berasal dari perkebunan perusahaan tersebut yang berlokasi di Banjar Tegeh, Desa Angseri, Kecamatan Baturiti, Kabupaten Tabanan.

Teh white peony dibuat tanpa melibatkan reaksi oksidasi enzimatis sama halnya dengan teh hijau, sehingga dapat dikatakan bahwa tahapan-tahapan pengolahan teh white peony hampir sama dengan teh hijau, yaitu pemetikan, pelayuan, penggulungan, dan pengeringan. Bahan baku pengolahan teh white peony adalah pucuk ditambah satu sampai dua daun dibawah pucuk $(\mathrm{p}+1-2)$,

*Korespondensi Penulis:

Email: triulandari88@yahoo.com ${ }^{1)}$ 
sedangkan teh hijau adalah pucuk ditambah satu sampai tiga daun di bawah pucuk $(\mathrm{p}+1-$ 3). Perbedaan teh white peony dengan teh hijau selain rumus petik adalah metode pelayuan serta banyaknya pengeringan selama proses pengolahan (Anon., 2017).

Bahan terpenting pada pengolahan teh putih adalah pucuk daun (peko) karena mengandung senyawa bioaktif tertinggi yang disebut polifenol dibandingkan bagian daun lainnya. Polifenol utama yang terdapat pada teh merupakan senyawa yang termasuk dalam kelas flavanol yaitu katekin (Hartoyo, 2003). Menurut Hilal dan Engelhardt (2007), kandungan total polifenol rata-rata pada teh putih adalah $21,54 \mathrm{~g} / 100 \mathrm{~g}$ serta kandungan katekin pada teh putih adalah $13,22 \mathrm{~g} / 100 \mathrm{~g}$.

Hasil penelitian menunjukkan bahwa penurunan jumlah katekin terbesar selama pengolahan teh terjadi pada tahap pelayuan $(7,40 \%)$ serta penggilingan $(6,70 \%)$ dan terkecil pada pengeringan akhir (1,60\%) (Syah, 2006). Pengeringan pada pengolahan teh white peony merupakan proses yang melibatkan panas secara langsung serta dalam waktu yang cukup lama. Panas yang diterima selama pengolahan dapat menyebabkan terjadinya epimerisasi yang dapat menyebabkan penurunanan jumlah katekin. Menurut penelitian Wang et al. (2008), katekin dapat mengalami epimerisasi pada suhu $98^{\circ} \mathrm{C}$. Menurut penelitian Saklar et al. (2015), katekin pada teh hijau Turki mengalami epimerisasi pada suhu $95^{\circ} \mathrm{C}$ yang mendapat perlakuan panas selama 45 menit. Menurut penelitian Seto et al. (1997), katekin mengalami epimerisasi ketika dipanaskan pada suhu $120^{\circ} \mathrm{C}$ selama 30 menit.

Beberapa penelitian mengenai pengaruh suhu pengeringan dalam pengolahan teh khususnya teh hijau terhadap kandungan bioaktif teh telah dilakukan seperti pada penelitian Roshanak et al. (2015) yang melaporkan bahwa suhu pengeringan $60^{\circ} \mathrm{C}$ menghasilkan total fenolik tertinggi yaitu 209,17 mg GAE/g serta aktivitas antioksidan tertinggi ( IC $_{50}$ terendah) yaitu $167,166 \mu \mathrm{g} / \mathrm{ml}$, sedangkan suhu pengeringan $100^{\circ} \mathrm{C}$ menghasilkan total flavonoid tertinggi yaitu $38,18 \mathrm{mg}$ QE/g. Menurut Setyopratomo (2014), suhu pengeringan yang digunakan selama proses pengolahan teh hijau untuk mempertahankan kandungan komponen bioaktifnya sebaiknya tidak melebihi $100^{\circ} \mathrm{C}$, sedangkan belum ada penelitian yang menyatakan suhu pengeringan yang tepat pada pengolahan teh white peony, maka dari itu, perlu dilakukan penelitian mengenai pengaruh suhu pengeringan terhadap komponen bioaktif dan krakteristik sensoris teh white peony.

\section{METODE PENELITIAN}

\section{Tempat dan Waktu}

Pengolahan teh white peony dilaksanakan di PT. Bali Cahaya Amerta yang berlokasi di Jln. Prof. Dr. Ida Bagus Mantra No.8, Desa Lebih, Kecamatan Gianyar, Kabupaten Gianyar. Proses analisis dilaksanakan di UPT. Laboratorium Analitik, Laboratorium Terpadu Biosains dan Bioteknologi, Analisis Pangan, Pengolahan Pangan, serta Biokimia dan Nutrisi Program Studi Ilmu dan Teknologi Pangan Fakultas Teknologi Pertanian Universitas Udayana. Penelitian ini dilaksanakan pada bulan April sampai dengan bulan Juli 2018.

\section{Bahan dan Alat}

Bahan-bahan yang digunakan dalam melaksanakan penelitian ini terdiri dari bahan baku dan bahan kimia. Bahan baku yang digunakan adalah daun teh varietas sinensis dengan rumus petik $\mathrm{p}+1-2$ yang diperoleh dari perkebunan PT. Bali Cahaya Amerta yang berlokasi di Banjar Tegeh, Desa Angseri, Kecamatan Baturiti, Kabupaten Tabanan. Bahan kimia yang digunakan antara lain: aseton 70\%, metanol (p.a), metanol $85 \%$, asam galat, reagen Folin-Ciocalteu, sodium karbonat $\left(\mathrm{Na}_{2} \mathrm{CO}_{3} 7,5 \%\right), \mathrm{AlCl}_{3} 10 \%, \mathrm{NaOH} 1$ 
M, DPPH (1,1-diphenyl-2-picrylhydrazil) $0,004 \%, \mathrm{Na}_{2} \mathrm{CO}_{3} \mathrm{0}, 5 \%$, standar katekin dan aquades.

Alat-alat yang digunakan dalam melaksanakan penelitian ini antara lain: tampah pelayuan, oven, termometer, blender (philips), ayakan 60 mesh, rotary evaporator vakum, tabung reaksi (pyrex), labu takar (pyrex), kertas saring Whatman no. 1, orbital shaker (biosan), gelas ukur (pyrex), erlenmeyer $250 \mathrm{ml}$ (pyrex), botol gelap, timbangan analitik (sartorius), mikropipet, pipet ukur (pyrex), cawan aluminium, spektrofotometer UV-Vis (biochrom) dan aluminium foil.

\section{Pelaksanaan Penelitian}

1. Pengolahan Teh White Peony

Pelaksanaan penelitian ini diawali dengan pengolahan teh white peony sebagai berikut.

a. Pemetikan daun teh

Pemetikan daun teh sebagai bahan baku teh white peony menggunakan rumus petik $(\mathrm{p}+1-2)$ yaitu pucuk (peko) ditambah satu sampai dua daun yang ada di bawah pucuk.

b. Sortasi

Setelah daun teh sampai di pabrik, dilakukan penerimaan bahan baku serta proses sortasi dengan memeriksa keadaan daun teh yang meliputi : kesesuaian rumus petik, keutuhan daun, dan kesegaran daun.

c. Pelayuan

Proses pelayuan dilakukan di ruang pelayuan pada suhu $27^{\circ} \mathrm{C}$ selama 20 jam dengan cara menghamparkan daun teh pada tampah pelayuan yang kemudian disusun pada rak-rak pelayuan, lalu diangin-anginkan dengan bantuan kipas angin untuk membuat sirkulasi udara lebih lancar serta pengaturan suhu dengan bantuan AC (Air Conditioner). Selanjutnya, dilakukan pelayuan kembali dengan sinar matahari secara tidak langsung selama kurang lebih satu jam hingga muncul aroma khas pada daun teh.

d. Pengukusan (Steaming)

Setelah memenuhi kriteria layu (pucuk layu yang berwarna hijau kekuningan, tidak mengering, tangkai muda menjadi lentur, bila digengam terasa lembut dan bila dilemparkan tidak akan buyar serta timbul aroma yang khas seperti buah masak), daun teh lalu dikukus dengan suhu $90^{\circ} \mathrm{C}$ selama 2 menit. Setelah itu diangin-anginkan kembali hingga dingin. Selanjutnya, dilakukan proses penggulungan.

e. Penggulungan

Penggulungan dilakukan dengan mesin Top Roller (TR) selama 5 menit hingga daun teh menggulung secara sempurna yang ditandai dengan daun menggulung dengan baik, bila dijatuhkan gulungannya tetap utuh, bila dipegang tidak menempel dan tidak mengeluarkan air, dan menghasilkan aroma yang khas.

f. Pengeringan

Proses pengeringan dilakukan dengan oven. Daun teh dimasukkan ke dalam oven dengan perlakuan suhu pengeringan $\left(60^{\circ} \mathrm{C}\right.$, $70^{\circ} \mathrm{C}, 80^{\circ} \mathrm{C}, 90^{\circ} \mathrm{C}$ dan $100^{\circ} \mathrm{C}$ ). Pengeringan dilakukan hingga daun teh memiliki ciri fisik : berwarna hijau kehitaman, muncul aroma khas seperti aroma karamel dan daun mudah dipatahkan serta akan hancur bila diremas. Proses pengeringan ini menyebabkan teh white peony memiliki kadar air 4-5\%. Untuk mencapai kadar air tersebut, proses pengeringan dilakukan selama 90 menit pada suhu $60^{\circ} \mathrm{C}, 80$ menit pada suhu $70^{\circ} \mathrm{C}, 70$ menit pada suhu $80^{\circ} \mathrm{C}, 60$ menit pada suhu $90^{\circ} \mathrm{C}$ dan 50 menit pada suhu $100^{\circ} \mathrm{C}$.

\section{Proses Pembuatan Ekstrak Teh White Peony}

Persiapan sampel untuk pengujian kadar total fenol, flavonoid, katekin dan aktivitas antioksidan dilakukan dengan metode ekstraksi. Ekstraksi sampel dilakukan dengan cara teh white peony dihancurkan dengan blender. Setelah itu dilakukan pengayakan dengan ayakan 60 mesh. Ditimbang sampel uji, dimasukkan ke dalam erlenmeyer dan dilarutkan dengan aseton $70 \%$ dengan perbandingan sampel dan pelarut adalah 1:10 
(b/v). Selanjutnya dishaker selama 60 menit dengan kecepatan $150 \mathrm{rpm}$, selanjutnya disaring dengan kertas saring whatman no.1. Filtrat yang diperoleh dipekatkan dengan rotary evaporator vakum pada suhu $30^{\circ} \mathrm{C}$ sehingga diperoleh ekstrak kasar daun teh (Druzynska, 2007 yang dimodifikasi; Shabri dan Rohdiana, 2016; Widarta dan Arnata, 2017). Ekstrak kasar tersebut kemudian dilakukan pengujian terhadap kadar total fenol, total flavonoid, katekin dan aktivitas antioksidan.

3. Proses Penyeduhan Teh White Peony untuk Pengujian Karakteristik Sensoris

Pengujian terhadap karakteristik sensoris teh white peony dilakukan oleh 15 orang panelis semi terlatih dengan metode skoring terhadap warna dan rasa serta hedonik terhadap warna seduhan, aroma, rasa dan penerimaan keseluruhan. Metode penyeduhan teh white peony yaitu : ditimbang sebanyak 2 g sampel (dalam bentuk daun) pada setiap perlakuan. Disiapkan air panas dengan suhu $80^{\circ} \mathrm{C}$ sebanyak $150 \mathrm{ml}$. Daun teh diletakkan di dalam teko porselin, kemudian diseduh dengan air tersebut dan didiamkan selama 5 menit. Sampel dengan perlakuan suhu pengeringan yang berbeda diberikan kode yang berbeda. Lalu disajikan pada gelas untuk diujikan kepada panelis.

\section{Parameter yang Diamati}

Parameter yang diamati dalam penelitian ini adalah kadar air (AOAC, 1995), rendemen ekstrak (Handayani et al., 2016), total fenol (Sakanaka et al., 2003), flavonoid (Chang et al., 2006), katekin (Ramlah, 2017) aktivitas antioksidan (Vasic et al., 2012 yang dimodifikasi), serta karakteristik sensoris yang meliputi: warna, rasa, aroma, dan peneriman keseluruhan terhadap seduhan teh white peony (Soekarto, 1985).

\section{HASIL DAN PEMBAHASAN}

Hasil analisis kadar air, rendemen, total fenol, flavonoid, katekin dan aktivitas antioksidan teh white peony dapat dilihat pada Tabel 1. Kadar total fenol, flavonoid, katekin dan aktivitas antioksidan dihitung dalam bahan kering $(\mathrm{b} / \mathrm{k})$.

Tabel 1. Nilai rata-rata kadar air, rendemen, total fenol, flavonoid, katekin dan aktivitas antioksidan teh white peony

\begin{tabular}{ccccccc}
\hline $\begin{array}{c}\text { Suhu } \\
\text { Pengeringan }\end{array}$ & $\begin{array}{c}\text { Kadar air } \\
(\% \mathrm{~b} / \mathrm{b})\end{array}$ & $\begin{array}{c}\text { Rendemen } \\
\text { ekstrak }(\%)\end{array}$ & $\begin{array}{c}\text { Total fenol } \\
(\mathrm{mg} \text { GAE/g teh })\end{array}$ & $\begin{array}{c}\text { Flavonoid } \\
(\mathrm{mg} \mathrm{CE} / \mathrm{g} \text { teh })\end{array}$ & $\begin{array}{c}\text { Katekin } \\
(\mathrm{mg} / \mathrm{g} \text { teh })\end{array}$ & $\begin{array}{c}\text { Aktivitas } \\
\text { antioksidan } \\
(\%)\end{array}$ \\
\hline $60^{\circ} \mathrm{C}$ & $6,88 \pm 0,01 \mathrm{a}$ & $42,95 \pm 2,2 \mathrm{c}$ & $159,63 \pm 5,6 \mathrm{c}$ & $6,45 \pm 0,2 \mathrm{e}$ & $2,60 \pm 0,1 \mathrm{c}$ & $43,28 \pm 2,2 \mathrm{c}$ \\
$70^{\circ} \mathrm{C}$ & $5,44 \pm 0,09 \mathrm{~b}$ & $46,15 \pm 0,8 \mathrm{~b}$ & $169,58 \pm 1,9 \mathrm{c}$ & $7,95 \pm 0,3 \mathrm{~d}$ & $3,06 \pm 0,02 \mathrm{~b}$ & $44,88 \pm 0,7 \mathrm{bc}$ \\
$80^{\circ} \mathrm{C}$ & $5,27 \pm 0,08 \mathrm{c}$ & $48,54 \pm 1,5 \mathrm{~b}$ & $180,60 \pm 7,6 \mathrm{~b}$ & $8,98 \pm 0,3 \mathrm{c}$ & $3,02 \pm 0,09 \mathrm{~b}$ & $46,85 \pm 1,7 \mathrm{~b}$ \\
$90^{\circ} \mathrm{C}$ & $4,06 \pm 0,05 \mathrm{~d}$ & $52,54 \pm 0,8 \mathrm{a}$ & $211,01 \pm 6,7 \mathrm{a}$ & $10,90 \pm 0,2 \mathrm{~b}$ & $3,55 \pm 0,04 \mathrm{a}$ & $50,20 \pm 1,0 \mathrm{a}$ \\
$100^{\circ} \mathrm{C}$ & $3,62 \pm 0,04 \mathrm{e}$ & $46,99 \pm 2,3 \mathrm{~b}$ & $146,21 \pm 3,7 \mathrm{~d}$ & $11,70 \pm 0,6 \mathrm{a}$ & $2,87 \pm 0,2 \mathrm{~b}$ & $43,95 \pm 2,6 \mathrm{bc}$ \\
\hline
\end{tabular}

Keterangan: Huruf yang sama dibelakang nilai rata-rata pada kolom yang sama menunjukkan perbedaan tidak nyata $(\mathrm{P}>0,05)$

\section{Kadar Air}

Hasil sidik ragam menunjukkan bahwa suhu pengeringan pada proses pengolahan berpengaruh sangat nyata $(\mathrm{P}<0,01)$ terhadap kadar air teh white peony. Rata-rata kadar air teh white peony dapat dilihat pada Tabel 1. Kadar air teh white peony berkisar antara $3,62 \%(b / b)$ hingga $6,88 \% \quad(b / b)$. Hal ini sesuai dengan Standar Nasional Indonesia (SNI 01-3836-2013) mengenai standar mutu teh (Camellia sinensis) kering dalam kemasan, yaitu kadar air maksimal adalah 8\% (b/b). Kadar air tertinggi diperoleh pada perlakuan suhu pengeringan $60^{\circ} \mathrm{C}$ yaitu $6,88 \%$, sedangkan kadar air terendah diperoleh pada perlakuan suhu pengeringan 
$100^{\circ} \mathrm{C}$ yaitu $3,62 \%$. Semakin tinggi suhu pengeringan maka terjadi penurunan kadar air. Menurut Taib et al. (1997) dalam Fitriani (2008), hal ini terjadi karena meningkatnya kemampuan suatu bahan untuk melepaskan air dari permukaannya seiring dengan meningkatnya suhu udara pengering. Menurut Winarno (1995), semakin tinggi suhu pengeringan maka semakin cepat terjadi penguapan, sehingga kandungan air di dalam bahan semakin rendah.

\section{Rendemen Ekstrak}

Hasil sidik ragam menunjukkan bahwa suhu pengeringan pada proses pengolahan berpengaruh sangat nyata $(\mathrm{P}<0,01)$ terhadap rendemen ekstrak teh white peony. Rata-rata rendemen ekstrak teh white peony dapat dilihat pada Tabel 1. Rendemen tertinggi diperoleh pada perlakuan suhu pengeringan $90^{\circ} \mathrm{C}$ yaitu $52,54 \%$ dan terendah pada suhu $60^{\circ} \mathrm{C}$ yaitu $42,95 \%$. Rendemen ekstrak mengalami peningkatan seiring dengan meningkatnya suhu pengeringan, namun mengalami penurunan pada suhu pengeringan $100^{\circ} \mathrm{C}$. Hal ini terjadi karena panas yang digunakan selama proses pengeringan dapat menyebabkan kerusakan protein, karbohidrat dan komponen-komponen penyusun dinding sel (Chu dan Juneja, 1997). Kerusakan komponen-komponen tersebut dapat menyebabkan membukanya sistem membran sel secara optimal, sehingga proses ekstraksi dapat terjadi lebih sempurna, namun pengeringan dengan suhu yang terlalu tinggi yaitu $100^{\circ} \mathrm{C}$ dapat menyebabkan penurunan rendemen pada ekstrak akibat membran sel membuka sangat maksimal yang akhirnya menyebabkan kerusakan terhadap komponenkomponen penyusun membran sel (Chu dan Juneja, 1997). Nilai rendemen dapat digunakan untuk memperkirakan banyaknya senyawa bioaktif yang terdapat pada bahan (Martono, 2016).

\section{Total Fenol}

Hasil sidik ragam menunjukkan bahwa suhu pengeringan pada proses pengolahan berpengaruh sangat nyata $(\mathrm{P}<0,01)$ terhadap kandungan total fenol teh white peony. Ratarata total fenol teh white peony dapat dilihat pada Tabel 1. Total fenol tertinggi diperoleh pada perlakuan suhu pengeringan $90^{\circ} \mathrm{C}$ yaitu $211,01 \mathrm{mg} \mathrm{GAE} / \mathrm{g}$ teh dan terendah pada suhu $100^{\circ} \mathrm{C}$ yaitu $146,21 \mathrm{mg}$ GAE/g teh. Semakin meningkatnya suhu pengeringan menyebabkan total fenol teh white peony semakin tinggi, namun suhu pengeringan yang terlalu tinggi yaitu pada suhu $100^{\circ} \mathrm{C}$ dapat menyebabkan penurunan kadar total fenol. Hal ini terjadi karena panas dapat menyebabkan terjadinya kerusakan terhadap komponen penyusun dinding sel daun yaitu karbohidrat (termasuk serat selulosa) dan protein sebagai komponen tidak terlarut. Kerusakan ini dapat memudahkan keluarnya senyawa polifenol dari dalam daun karena polifenol merupakan senyawa yang memiliki berat molekul rendah, sehingga mudah untuk terinfusi ke dalam pelarut (Chu dan Juneja, 1997). Proses pemanasan saat pengeringan juga berfungi untuk menginaktivasi enzim polifenol oksidase (Tuminah, 2004). Semakin tinggi suhu pengeringan mengakibatkan peningkatan proses inaktivasi enzim polifenol oksidase, sehingga aktivitas enzim akan semakin rendah dan kerusakan senyawa polifenol semakin sedikit, namun jika suhu pengeringan melampaui suhu optimum, maka stabilitas senyawa polifenol akan terganggu sehingga dapat menyebabkan penurunan kandungan senyawa polifenol pada bahan (Susanti, 2008).

\section{Total Flavonoid}

Hasil sidik ragam menunjukkan bahwa suhu pengeringan pada proses pengolahan berpengaruh sangat nyata $(\mathrm{P}<0,01)$ terhadap kandungan flavonoid teh white peony. Ratarata kandungan flavonoid teh white peony dapat dilihat pada Tabel 1. Kandungan flavonoid tertinggi diperoleh pada perlakuan 
suhu pengeringan $100^{\circ} \mathrm{C}$ yaitu $11,70 \mathrm{mg} \mathrm{CE} / \mathrm{g}$ teh dan terendah pada suhu $60^{\circ} \mathrm{C}$ yaitu 6,45 $\mathrm{mg} \mathrm{CE} / \mathrm{g}$ teh. Hal ini terjadi karena proses pengeringan pada daun teh segar dapat menghancurkan lapisan lilin yang ada di permukaan luar daun dan selanjutnya akan memecah dinding sel sehingga akan memudahkan senyawa flavonoid untuk berdifusi ke dalam pelarut (Setyopratomo, 2014). Semakin tinggi suhu pengeringan menyebabkan semakin tinggi pula kerusakan terhadap dinding sel, sehingga semakin tinggi jumlah senyawa flavonoid yang berdifusi ke dalam pelarut. Komponen flavonoid yang banyak terdapat di dalam daun teh adalah katekin, flavonol glikosida, dan flavon Cglikosida (Handoko, 2007). Menurut Jeong et al. (2004), perlakuan pemanasan pada bahan dapat menyebabkan keluarnya beberapa senyawa fenolik dengan berat molekul rendah, dimana flavonoid yang terdapat pada teh merupakan senyawa fenolik yang memiliki berat molekul rendah. Pernyataan ini sesuai dengan hasil penelitian yang diperoleh yaitu ketika teh white peony dipanaskan pada suhu $100^{\circ} \mathrm{C}$, masih memungkinkan senyawa flavonoid untuk keluar dari dalam sel khususnya dari bagian vakuola sel, sehingga didapatkan kadar flavonoid yang lebih tinggi dibandingkan dengan perlakuan suhu pengeringan lainnya.

\section{Katekin}

Hasil sidik ragam menunjukkan bahwa suhu pengeringan pada proses pengolahan berpengaruh sangat nyata $(\mathrm{P}<0,01)$ terhadap kandungan katekin teh white peony. Rata-rata kandungan katekin teh white peony dapat dilihat pada Tabel 1. Kandungan katekin tertinggi diperoleh pada perlakuan suhu pengeringan $90^{\circ} \mathrm{C}$ yaitu $3,55 \mathrm{mg} / \mathrm{g}$ teh dan terendah pada suhu $60^{\circ} \mathrm{C}$ yaitu $2,60 \mathrm{mg} / \mathrm{g}$ teh. Pengeringan pada suhu 70,80 dan $100^{\circ} \mathrm{C}$ menunjukkan perbedaan tidak nyata terhadap kandungan katekin teh white peony. Kadar katekin mengalami peningkatan seiring meningkatnya suhu pengeringan sampai mencapai titik optimum dan akhirnya mengalami penurunan. Katekin merupakan senyawa yang kurang stabil dan mudah mengalami kerusakan yang disebabkan oleh panas yang berlebih selama proses pengeringan (Nindyasari, 2012). Suhu pengeringan yang melebihi $90^{\circ} \mathrm{C}$ selama pengeringan teh white peony, dapat menyebkan kerusakan pada katekin. Katekin yang utama dalam teh adalah epicatechin (EC), epicatechin gallate (ECG), epigallocatechin (EGC), dan epigallocatechin gallate (EGCG). Jika katekin mengalami kerusakan oleh panas, maka EGCG, ECG, EGC dan EC akan mengalami epimerisasi menjadi gallocatechin gallate (GCG), catechin gallate (CG), gallocatechin (GC), dan catechin (C) (Chen et al., 2001). Epimerisasi ini menyebabkan kadar katekin total akan menurun (Setyopratomo, 2014). Hal ini sesuai dengan penelitian Wang et al., 2008, yaitu katekin dapat mengalami epimerisasi pada suhu $98^{\circ} \mathrm{C}$ dimana epimerisasi ini menyebabkan menurunnya total katekin seiring dengan meningkatnya suhu pemanasan.

\section{Aktivitas Antioksidan}

Hasil sidik ragam menunjukkan bahwa suhu pengeringan pada proses pengolahan berpengaruh sangat nyata $(\mathrm{P}<0,01)$ terhadap aktivitas antioksidan teh white peony. Ratarata aktivitas antioksidan teh white peony dapat dilihat pada Tabel 1. Aktivitas antioksidan tertinggi diperoleh pada perlakuan suhu pengeringan $90^{\circ} \mathrm{C}$ yaitu $50,20 \%$ dan terendah pada suhu $60^{\circ} \mathrm{C}$ yaitu $43,28 \%$. Perlakuan pengeringan pada suhu 70 dan $100^{\circ} \mathrm{C}$ menunjukkan perbedaan tidak nyata terhadap aktivitas antioksidan teh white peony. Aktivitas antioksidan teh white peony dipengaruhi oleh kadar total fenol, flavonoid dan katekin.

Suhu pengeringan yang terlalu tinggi yaitu $100^{\circ} \mathrm{C}$ menyebabkan penurunan terhadap 
aktivitas antioksidan. Hal ini terjadi karena katekin yang terdapat pada daun teh merupakan metabolit sekunder yang termasuk senyawa polifenol dan tergolong sebagai flavonoid yang memiliki sifat tidak tahan terhadap panas yang terlalu tinggi. Katekin merupakan senyawa yang memiliki sifat sebagai antioksidan (Hasanah, 2012). Gugus hidroksil fenolik yang dimiliki oleh katekin merupakan donor elektron yang potensial untuk berikatan dengan radikal bebas (Ramlah, 2017). Menurut Handoko (2007), polifenol katekin memiliki aktivitas antioksidan lebih besar jika dibandingkan dengan vitamin $\mathrm{C}$ atau $\beta$-karoten.

Perlakuan dengan aktivitas antioksidan tertinggi yaitu pada suhu pengeringan $90^{\circ} \mathrm{C}$ dilakukan pengujian terhadap $\mathrm{IC}_{50}$. Nilai $\mathrm{IC}_{50}$ diperoleh pada konsentrasi 4,97 mg/L. Hal ini berarti bahwa pada konsentrasi 4,97 mg/L, teh white peony dapat menghambat radikal bebas sebanyak 50\%. Nilai $\mathrm{IC}_{50}$ yang semakin kecil, menunjukkan kemampuan antioksidan yang lebih tinggi dalam menangkal radikal bebas. Bahan yang memiliki nilai $\mathrm{IC}_{50}$ sebesar $<50$ ppm memiliki sifat antioksidan yang sangat kuat (Molyneux, 2004). Teh white peony memiliki nilai $\mathrm{IC}_{50}$ sebesar $4,97 \mathrm{mg} / \mathrm{L}$, sehingga dapat digolongkan sebagai bahan yang memiliki sifat antioksidan sangat kuat.

\section{Sifat Sensoris}

Evaluasi sensoris teh white peony dilakukan dengan uji hedonik dan skoring. Uji hedonik dilakukan terhadap warna, rasa, arocma dan penerimaan keseluruhan. Nilai rata-rata uji hedonik terhadap warna, rasa, aroma dan penerimaan keseluruhan teh white peony dapat dilihat pada Tabel 2. Nilai ratarata uji skoring terhadap warna dan rasa teh white peony dapat dilihat pada Tabel 3.

Tabel 2. Nilai rata-rata uji hedonik terhadap warna, rasa, aroma dan penerimaan keseluruhan teh white peony

\begin{tabular}{cccll}
\hline $\begin{array}{c}\text { Suhu } \\
\text { Pengeringan }\end{array}$ & Warna & Rasa & Aroma & Penerimaan keseluruhan \\
\hline $60^{\circ} \mathrm{C}$ & $6,07 \pm 0,5 \mathrm{a}$ & $5,93 \pm 0,5 \mathrm{a}$ & $6,07 \pm 0,5 \mathrm{ab}$ & $5,87 \pm 0,6 \mathrm{a}$ \\
$70^{\circ} \mathrm{C}$ & $6,20 \pm 0,6 \mathrm{a}$ & $5,20 \pm 1,1 \mathrm{~b}$ & $6,33 \pm 0,6 \mathrm{a}$ & $5,53 \pm 0,9 \mathrm{ab}$ \\
$80^{\circ} \mathrm{C}$ & $6,00 \pm 0,7 \mathrm{a}$ & $5,60 \pm 1,0 \mathrm{ab}$ & $5,73 \pm 0,6 \mathrm{bc}$ & $5,80 \pm 0,7 \mathrm{ab}$ \\
$90^{\circ} \mathrm{C}$ & $6,07 \pm 0,6 \mathrm{a}$ & $4,47 \pm 1,4 \mathrm{c}$ & $5,67 \pm 0,5 \mathrm{c}$ & $5,47 \pm 0,6 \mathrm{~b}$ \\
$100^{\circ} \mathrm{C}$ & $6,00 \pm 0,5 \mathrm{a}$ & $5,40 \pm 0,8 \mathrm{~b}$ & $6,00 \pm 1,0 \mathrm{abc}$ & $5,73 \pm 1,0 \mathrm{ab}$ \\
\hline
\end{tabular}

Keterangan : Huruf yang sama dibelakang nilai rata-rata pada kolom yang sama menunjukkan perbedaan tidak nyata $(\mathrm{P}>0,05)$

Kriteria hedonik : 1 (sangat tidak suka); 2 (tidak suka); 3 (agak tidak suka); 4 (biasa); 5 (agak suka); 6 (suka); 7 (sangat suka)

Tabel 3. Nilai rata-rata uji skoring terhadap warna dan rasa teh white peony

\begin{tabular}{|c|c|c|}
\hline Suhu Pengeringan & Warna & Rasa \\
\hline $60^{\circ} \mathrm{C}$ & $2,93 \pm 0,5 \mathrm{c}$ & $3,73 \pm 0,6 \mathrm{a}$ \\
\hline $70^{\circ} \mathrm{C}$ & $3,47 \pm 0,6 \mathrm{a}$ & $2,73 \pm 0,7 \mathrm{~b}$ \\
\hline $80^{\circ} \mathrm{C}$ & $3,20 \pm 0,4 \mathrm{~b}$ & $3,07 \pm 0,7 \mathrm{~b}$ \\
\hline $90^{\circ} \mathrm{C}$ & $3,33 \pm 0,5 \mathrm{ab}$ & $2,33 \pm 1,0 \mathrm{c}$ \\
\hline $100^{\circ} \mathrm{C}$ & $2,67 \pm 0,5 \mathrm{~d}$ & $3,80 \pm 0,7 \mathrm{a}$ \\
\hline \multicolumn{3}{|c|}{$\begin{array}{ll}\text { Keterangan: Huruf yang sama dibelakang nilai rata-rata pada kolom yang sama menunjukkan perbedaan tidak nyata } \\
(\mathrm{P}>0,05)\end{array}$} \\
\hline \multicolumn{3}{|c|}{$\begin{array}{ll}\text { Nilai skoring warna }: & 1 \text { (bening);2 (kuning muda); } 3 \text { (kuning); } 4 \text { (kuning tua); } \\
& 5 \text { (kuning kecokelatan) } \\
\text { Nilai skoring rasa }: & 1 \text { (sangat sepat); } 2 \text { (sepat); } 3 \text { (agak sepat); } 4 \text { (agak tidak sepat); } 5 \text { (tidak sepat) }\end{array}$} \\
\hline Nilai skoring rasa & pat); 3 (agak se & idak sepat) \\
\hline
\end{tabular}




\section{Warna}

Hasil sidik ragam menunjukkan bahwa suhu pengeringan berpengaruh tidak nyata $(\mathrm{P}>0,05)$ terhadap warna seduhan teh white peony yang dilakukan dengan uji hedonik. Rata-rata hasil uji hedonik terhadap warna seduhan teh white peony dapat dilihat pada Tabel 2. Nilai rata-rata kesukaan panelis terhadap warna seduhan teh white peony berkisar antara 6,00-6,20 dengan kriteria suka. Kesukaan panelis terhadap warna seduhan teh white peony kemudian dilanjutkan dengan uji skoring.

Hasil sidik ragam menunjukkan bahwa suhu pengeringan berpengaruh sangat nyata $(\mathrm{P}<0,01)$ terhadap warna seduhan teh white peony yang dilakukan dengan uji skoring. Rata-rata hasil uji skoring terhadap warna seduhan teh white peony dapat dilihat pada Tabel 3. Nilai rata-rata warna seduhan teh white peony berkisar antara 2,67-3,47 dengan kriteria warna seduhan adalah kuning. Kadar flavonoid tertinggi dapat dilihat dari warna seduhan yang dihasilkan. Warna yang lebih pekat menunjukkan kadar flavonoid yang tinggi dengan aktivitas antioksidan yang tinggi pula (Ramlah, 2017). Flavonoid dapat memberi warna kuning kecokelatan pada seduhan dan akan berubah menjadi cokelat gelap bila terjadi reaksi oksidasi lebih lanjut (Winardi, 2010). Perlakuan suhu pengeringan 70,80 dan $90^{\circ} \mathrm{C}$ memberikan perbedaan tidak nyata terhadap warna seduhan teh white peony yaitu cenderung berwarna kuning, sedangkan suhu pengeringan 60 dan $100^{\circ} \mathrm{C}$ menyebabkan warna kuning yang lebih muda karena mengandung senyawa flavonoid yang lebih sedikit.

\section{Rasa}

Hasil sidik ragam menunjukkan pengaruh sangat nyata $(\mathrm{P}<0,01)$ terhadap rasa teh white peony yang dilakukan dengan uji hedonik. Rata-rata hasil uji hedonik atau kesukaan terhadap rasa teh white peony dapat dilihat pada Tabel 2. Nilai rata-rata kesukaan panelis terhadap rasa teh white peony berkisar antara 4,47-5,93 dengan kriteria biasa-suka. Rasa sepat yang ada pada seduhan teh white peony cenderung menurunkan tingkat kesukaan panelis, sehingga untuk mengetahui tingkat kesepatan rasa teh white peony, dilanjutkan dengan uji skoring.

Hasil sidik ragam menunjukkan bahwa suhu pengeringan berpengaruh sangat nyata $(\mathrm{P}<0,01)$ terhadap rasa teh white peony yang dilakukan dengan uji skoring. Rata-rata hasil uji skoring terhadap rasa teh white peony dapat dilihat pada Tabel 3. Nilai rata-rata rasa teh white peony berkisar antara 2,33-3,80 dengan kriteria sepat-agak tidak sepat. Perlakuan suhu pengeringan 60 dan $100^{\circ} \mathrm{C}$ cenderung menimbulkan rasa agak tidak sepat pada seduhan teh white peony, suhu pengeringan 70 dan $80^{\circ} \mathrm{C}$ cenderung menimbulkan rasa agak sepat serta suhu pengeringan $90^{\circ} \mathrm{C}$ cenderung menimbulkan rasa sepat. Rasa sepat yang timbul disebabkan adanya senyawa katekin. Katekin dapat memberi rasa pahit dan sepat pada seduhan teh (Ramlah, 2017), sehingga semakin tinggi kandungan katekin pada teh white peony maka rasa dari teh tersebut akan semakin sepat. Epicatechin (EC) dan epigallocatechin (EGC) yang merupakan bagian dari katekin, mampu memunculkan rasa sedikit sepat dengan sedikit manis setelah diminum, sedangkan bentuk gallatenya (EGC dan EGCG) memunculkan rasa sepat yang kuat (Yamanishi, 1991 dalam Mitrowihardjo, 2012).

\section{Aroma}

Hasil sidik ragam menunjukkan bahwa suhu pengeringan berpengaruh sangat nyata $(\mathrm{P}<0,01)$ terhadap aroma teh white peony yang dilakukan dengan uji hedonik atau kesukaan. Rata-rata hasil uji hedonik terhadap aroma teh white peony dapat dilihat pada Tabel 2. Nilai rata-rata aroma teh white peony berkisar antara 5,67-6,33 dengan kriteria suka. Menurut Ciptadi dan Nasution (1979), 
senyawa pembentuk aroma teh terutama terdiri dari minyak atsiri yang bersifat mudah menguap dan bersifat mudah direduksi sehingga dapat menghasilkan aroma harum pada teh, selain itu teh juga mengandung senyawa asam galat. Ketika terjadi proses pengeringan pada teh, asam galat akan teroksidasi menjadi senyawa thearubigin (TR). Senyawa thearubigin bertanggungjawab pada aroma harum yang ada pada seduhan teh (Kim et al., 2011).

\section{Penerimaan keseluruhan}

Hasil sidik ragam menunjukkan bahwa suhu pengeringan berpengaruh tidak nyata $(\mathrm{P}>0,05)$ terhadap penerimaan keseluruhan teh white peony yang dilakukan dengan uji hedonik atau kesukaan. Rata-rata hasil uji hedonik terhadap penerimaan keseluruhan teh white peony dapat dilihat pada Tabel 2. Nilai rata-rata penerimaan keseluruhan teh white peony berkisar antara 5,47-5,87 dengan kriteria agak suka-suka. Perlakuan suhu pengeringan 60,80 dan $100^{\circ} \mathrm{C}$ cenderung disukai panelis, sedangkan suhu pengeringan 70 dan $90^{\circ} \mathrm{C}$ cenderung agak disukai panelis. Karakteristik sensoris yang sangat mempengaruhi penerimaan keseluruhan panelis terhadap teh white peony adalah rasa seduhan teh, sehingga semakin sepat rasa seduhan teh white peony, kesukaan panelis akan menurun.

\section{SIMPULAN DAN SARAN}

\section{Simpulan}

Berdasarkan hasil penelitian, dapat disimpulkan hal-hal sebagai berikut.

1. Suhu pengeringan pada proses pengolahan teh white peony berpengaruh sangat nyata terhadap kadar air, rendemen ekstrak, total fenol, flavonoid, katekin, aktivitas antioksidan, warna (uji skoring), rasa (uji skoring dan hedonik) serta aroma (uji hedonik).

2. Suhu pengeringan $90^{\circ} \mathrm{C}$ menghasilkan teh white peony dengan kandungan komponen bioaktif tertinggi dan karakteristik sensoris terbaik yaitu : kadar air $4,06 \%$, rendemen $52,54 \%$, kadar total fenol $211,01 \mathrm{mg}$ $\mathrm{GAE} / \mathrm{g}$ teh, flavonoid $10,90 \mathrm{mg} \mathrm{CE} / \mathrm{g}$ teh, katekin 3,55 $\mathrm{mg} / \mathrm{g}$ teh, aktivitas antioksidan 50,20\%, warna seduhan kuning dan disukai, rasa sepat dan biasa, aroma disukai dan penerimaan keseluruhan agak suka.

\section{Saran}

Adapaun saran yang dapat diberikan yaitu proses pengeringan dalam pengolahan teh white peony untuk memperoleh produk teh dengan kandungan komponen bioaktif tertinggi dan karakterisrik sensoris terbaik sebaiknya dilakukan pada suhu $90^{\circ} \mathrm{C}$ selama 60 menit hingga memiliki ciri fisik yaitu daun berwarna hijau kehitaman, muncul aroma khas seperti aroma karamel, daun mudah dipatahkan serta akan hancur bila diremas.

\section{DAFTAR PUSTAKA}

Anonimus. 2013. Teh Putih yang Langka dan Mahal.

http://balittri.litbang.pertanian.go.id/ index.php/berita/info-teknologi/177-teh putih-yang-langka-dan-mahal.Diakses tanggal 21 Oktober 2018.

Anonimus. 2017. Proses Pengolahan dan Standar Mutu Teh White peony. PT. Bali Cahaya Amerta, Denpasar.

AOAC, 1995. Official Methods of Analysis. Association of Official Analytical Chemists. Benjamin Franklin Station, Washington DC.

Ciptadi, W. dan M. Z. Nasution. 1979. Mempelajari Cara Pemanfaatan Teh Hitam Mutu Rendah untuk Pembuatan Teh Dadak. Institut Pertanian Bogor, Bogor.

Chang, Q., Z. Zuo, M.S.S. Chow danW.K.K. Ho. 2006. Effect of storage temperature 
on phenolics stability in hawthorn (Crataegus pinnatifda Var. Major) fruits and a hawthorn drink. Food Chemistry. 98(3):426-430.

Chen, Z.Y., Q.Y. Zhu., D. Tsang., Y. Huang. 2001. Degradation of green tea catechin in tea drinks. Journal of Agriculture and Food Chemistry. 49:477-482.

Chu, D.C dan L.R. Juneja. 1997. General Chemical Composition of Green Tea and Its Infusion Chemistry and Applications of Green Tea. CRC Press LLC., USA, p.13- 21.

Druzynska, B., A. Stepniewska dan R. Wołosiak. 2007. The influence of time and type of solvent on efficiency of the extraction of polyphenols from green tea and antioxidant properties obtained extracts. Journal of Technologia Alimentaria. 6(1): 27-36.

Fitriani, S. 2008. Pengaruh suhu dan lama pengeringan terhadap beberapa mutu manisan belimbing wuluh (Averrhoabellimbi L.). Jurnal SAGU. 7(1):32-37.

Handoko, D. 2007. Pengaruh Tekanan Dan Suhu Pada Kondisi Evaporasi Ekstrak Daun Teh Hijau. Skripsi. Tidak dipublikasikan. Fakultas Matematika Dan Ilmu Pengetahuan Alam Institut Pertanian Bogor, Bogor.

Handayani, H., F.H. Srihefyna dan Yunianta. 2016. Ekstraksi antioksidan daun sirsak metode ultrasonic bath (kajian rasio bahan: pelarut dan lama ekstraksi). Jurnal Pangan dan Agroindustri. 4(1):262-272.

Hartoyo, A. 2003. Teh dan Khasiatnya bagi Kesehatan. Kanisius, Yogyakarta.

Hasanah, S.U., S. Hamdani dan A. Firmansyah. 2012. Perbandingan kadar katekin dari beberapa jenis kualitas teh hitam (camellia sinensis 1.[o] kuntze) di pusat penelitian teh dan kina (pptk) gambung. Indonesian Journal of Pharmaceutical Science and Technology. 1(1):7-12.

Hilal, Y dan U. Engelhardt. 2007. Characterisation of white tea comparison to green and black tea. Journal of Consumer Protection and Food Safety. 2:414-421.

Jeong, S. M., S.Y. Kim., D.R. Kim., S.C. Jo., K.C. Nam., D.U. Ahn dan S.C. Lee. 2004. Effect of heat treatment on the antioxidant activity of extracts from citrus peels. Journal of Agricultural and Food Chemistry. 52:3389-3393.

Kim, Y., K.L. Goodner., J. Park., J. Choi dan S.T. Talcott. 2011. Changes in antioxidant phytochemical and volatile composition of Camellia sinensis by oxidation during tea fermentation. Food Chem. 129:1331-1342.

Martono, B., S. Falah dan E. Nurlela. 2016. Aktivitas antioksidan teh varietas gmb 7 pada beberapa ketinggian tempat. J. TIDP. 3(1):53-60.

Mitrowihardjo, S. 2012. Kandungan Katekin Dan Hasil Pucuk Beberapa Klon Teh (Camelia sinensis (L.) O. Kuntze) Unggulan pada Ketinggian yang Berbeda di Kebun Pagilaran. Disertasi. Tidak dipublikasikan. Fakultas Pertanian UGM, Yogyakarta.

Molyneux, P. 2004. The use of stable radical diphenylpicril-hydrazyl (dpph) for estimating antioxidant activity. Songklanakarin Journal of Science Technology. 26(2):211-219.

Nindyasari, S. 2012. Pengaruh Suhu dan Waktu Penyeduhan Teh Hijau (Camellia sinensis) serta Proses Pencernaan In 
Vitro terhadap Aktivitas Inhibisi Lipase. Skripsi. Tidak dipublikasikan. Fakultas Teknologi Pertanian IPB, Bogor.

Ramlah. 2017. Penentuan Suhu Dan Waktu Optimum Penyeduhan Daun Teh Hijau (Camellia Sintesis L.) P+2 Terhadap Kandungan Antioksidan Kafein, Tanin Dan Katekin. Skripsi. Tidak dipublikasikan. Fakultas Sains dan Teknologi UIN Alauddin, Makassar.

Roshanak, S., M. Rahimmalek dan S.A.H. Goli. 2015. Evaluation of seven different drying treatments in respect to total flavonoid, phenolic, vitamin $\mathrm{c}$ content, chlorophyll, antioxidant activity and color of green tea (Camellia sinensis or C. Assamica) leaves. Journal of Food Science Technology. 53(1):721-729.

Sakanaka, S., Y. Tachibana., Y. Okada. 2003. Preparationand antioxiant properties of extracts of Japanese persimo leaf tea (kakinocha-cha). Food chemistry. 89:569-575.

Saklar, S., E. Ertas., S. Ibrahim., Ozdemir dan B. Karadeniz. 2015. Effects of different brewing conditions on catechin content and sensory acceptance in Turkish green tea infusions. J Food Sci Technol. DOI 10.1007/s13197-015-1746-y.

Seto, R., H. Nakamura., F. Nanjo dan Y. Hara. 1997. Preparation of epimers of tea catechins by heat treatment. Journal of Bioscience, Biotechology and Biochcmistry. 61(9):1434-1439.

Setyopratomo, P. 2014. Extraction of phenolic compounds from green tea using ethanol. Journal of Engineering and Applied Sciences. 9(9):1516-1521.

Shabri dan D. Rohdiana. 2016. Optimasi Dan Karakterisasi Ekstrak Polifenol The
Hijau Dari Berbagai Pelarut. Jurnal Penelitian Teh dan Kina. 19(1):57-66.

Soekarto, S.T. 1985. Penilaian Organoleptik untuk Industri Pangan dan Hasil Pertanian, Bhratara Aksara, Jakarta.

Susanti, D.Y. 2008. Efek Suhu Pengeringan terhadap Kandungan Fenolik dan Kandungan Katekin Ekstrak Daun Kering Gambir. Prosiding Seminar Nasional Teknik Pertanian Universitas Gadjah Mada, Yogyakarta.

Syah, A.N.A. 2006. Taklukkan Penyakit dengan Teh Hijau. PT. Agromedia Pustaka, Tangerang.

Taib, G., G. Said dan S. Wiraatmadja. 1997. Operasi Pengeringan Pada Pengolahan Hasil Pertanian. Mediyatama Sarana Perkasa, Jakarta.

Tuminah S. 2004. Teh [Camellia sinensis o. k var. assamica (mast)] sebagai salah satu sumber antioksidan. J Cermin Dunia Kedokteran. 144:52-54.

Vasic, S.M., O.D. Stefanovic., B.Z. Licina., I.D. Radojevic dan L.R. Comic. 2012. Biological activities of extracts from cultivated Granadilla passiflora alata. EXLI Journal. 11:20821-ISSN 16112156.

Wang, R., W. Zou dan X. Jiang. 2008. Reaction kinetics of degradation and epimerization of epigallocatechin gallate (egcg) in aqueous system over a wide temperature range. Journal of Agricultural and Food Chemistry. 56(8): 2694-2701.

Widarta, I.W.R dan I.W. Arnata. 2017. Ekstraksi komponen bioaktif daun alpukat dengan bantuan ultrasonik pada berbagai jenis dan konsentrasi pelarut. Jurnal Agritech. 37(2):148-157. 
Winardi, R.R. 2010. Perubahan kadar flavonoid selama fermentasi seduhan teh hijau dan potensi khasiatnya. Jurnal Saintech. 2(3):63-68.

Winarno, F.G. 1995. Kimia Pangan dan Gizi. Gramedia Pustaka Utama, Jakarta.

Yamanishi, T. 1999. Tea Plavor. In Jain N.K. (Ed). Global Advances in Tea Science. Aravali Book International Ltd., New Delhi, p. 707-722. 